\title{
Accounting for Accounting's Role in the Neoliberalization Processes of Social Housing in England: A Bourdieusian Perspective
}

\begin{abstract}
This paper seeks to account for how accounting is implicated in the neoliberalization processes of social housing in England. It adopts a processual view which instead of conceptualizing neoliberalism as static and 'end-state', views it as a dynamic process of neoliberalization. We draw upon Bourdieu's notions of field, capital and habitus to frame our study. We focus on reform of the regulation of social housing in England during the period 2006 -2016. We show that the process of neoliberaliztion of social housing in England was instigated by the state's intervention to change the structure of the field in terms of norms, power relations and positions of players on the field. These changes brought about simultaneous changes in the habitus of the field as well as the structure and habitus of Housing Associations as sub-fields. We demonstrate how these changes create and reproduce a new system of domination where the tenant is the dominated player. We highlight the role accounting played in these changes in terms of being used as a tool by the regulator to achieve social control and drive change within Housing Associations and by the Housing Associations to evidence conformity with the new norms and adaptation.
\end{abstract}




\title{
Accounting for Accounting's Role in the Neoliberalization Processes of Social Housing in England: A Bourdieusian Perspective
}

\section{Introduction}

\begin{abstract}
"It is, therefore, legitimate to seek to confront accounting with an analysis of the specific consequences which it has had. What has been changed in the name of accounting both within the organisation and without? ...... And how do any such precise consequences of specific accountings relate to the missions and rationales which mobilized them in the first place? Although such an examination should not be alien to the accounting perspective, accounting itself has only rarely been accounted for." (Hopwood, 1994 pp. 158)
\end{abstract}

Over the past four decades' neoliberalism has established itself as the dominant discourse in the global political economy. Indeed, Anderson (2000a: pp.17) describes it as the 'most successful ideology in world history'. It has driven reforms of public services all around the globe (Harvey, 2007) in form of deregulation, privatization, the introduction of private sector management practices into the public sector and the dismantling of the welfare state (Morales et al., 2014; Jupe and Funnell, 2015). These neoliberal reforms are usually underpinned by the objective of extending market mechanisms to the public services (Chiapello, 2016). Along with other public services, social housing in the UK has been significantly impacted by these reforms including the right to buy policy which gives social housing tenants the right to buy the house they are living in at a discounted rate thus depleting the stock of social housing ${ }^{1}$, the privatization of council housing through large scale voluntary transfers (LSVTs) ${ }^{2}$ of council housing stock to housing associations run on business-like principles (Smyth, 2012; Daly et al. 2005) and more recently a reshaping of the way social housing is regulated in England.

Critical accounting scholarship has sought to critic the relationship between accounting and neoliberalism with much of the work focusing on how accounting has been harnessed to provide a rational for neoliberal reforms (Dillard, 1991; Cooper, 1995; Parker, 2011; Fourcade and Healy, 2013), its political potency (Rose, 1991; Fourcade and Healy, 2013) its significance in implementing neoliberal policies (Jupe and Funnell, 2015; Zhang et al., 2012) and its role in resisting neoliberalism (Andrew and Cahill, 2016; Smyth, 2012). Only a few of these studies are set in the context of social housing (Smyth, 2012; Collier, 2005). This limited focus on the social housing sector is not a trivial issue as the social housing sector in England accounts for 4.19 million homes representing 17.3\% of the total housing stock in England (DCLG, 2017). Indeed, the importance as well as the marginalization of the English social housing sector is highlighted in the public discourse following the recent Grenfell fire disaster in London (Mckee, 2017) in which 72 people died.

We argue that the existing critical accounting research which explores the relationship between accounting and neoliberalism only partly accounts for the role accounting plays in bringing

\footnotetext{
${ }^{1}$ In England 1.91 million homes have been sold under the Right to Buy since it was introduced in 1980 (Source, DCLG Annual Right to Buy Sales for England live table available at https://www.gov.uk/government/statisticaldata-sets/live-tables-on-social-housing-sales

${ }^{2} \mathrm{~A}$ list of all acronyms used in this paper and their meanings is contained in Appendix 1.
} 
about neoliberal change as the literature views both neoliberalism and accounting as static phenomena. This study posits an alternative approach drawn from the geography and politics literature which takes a processual view of neoliberalism as the process of 'neoliberalization' (Ward and England, 2007; Tickell and Peck, 2003). We also draw on the accounting and society literature which views accounting as a dynamic and diverse phenomenon which impacts and is impacted upon by the context in which it operates (Hopwood, 1983; Gallhofer et al., 2015; Jackson et al., 2013).

Taking a processual view of neoliberalism allows us to delve into the 'black box' of the inner workings of neoliberalism and what role accounting plays in these. It allows us to pose the hitherto unanswered question of: How is accounting implicated in the process of neoliberalizing society? We explore this question in the context of the recent neoliberal regulatory reforms implemented in the social housing sector in the UK. In doing this, we respond to the call to account for accountings role in Neoliberalism (Hopwood, 1994; Chiapello, 2016) as well as the call to extend research on the process of regulation (Artiach et al., 2016; Young, 1994, 1995; Malsch and Gendron, 2011; MacDonald and Richardson, 2004; Canning and O'Dwyer 2013). In so doing, we specify the research question for this study as: How is accounting implicated in the process of introducing the new regulatory framework for social housing in England?

In orienting towards process and practice we draw on works of Pierre Bourdieu to help us develop an understanding of how accounting is implicated in the processes and practices of neoliberalizing the English social housing sector. We draw particularly on his concepts of field, capital and habitus (Bourdieu, 1977, 1984a, 1986, 1990, 2005; Bourdieu and Wacquant, 1992).

We highlight the stages in the process of neoliberalizing the English social housing field, showing how the state intervenes in the field to introduce and naturalize a logic of economics over a social logic and how this creates and reproduces a new system of domination where the tenants become the dominated players on the field. Thus challenging the dominant view within the critical accounting literature of neoliberalism as 'static' and 'end state'. We highlight the role of accounting in the process by showing how it is used as a tool for achieving social control, redefining power relations in the field and driving organisational change in Housing Associations (HAs). In doing this, we demonstrate the value of Bourdieu's theories of field, capital and habitus in theorising accounting's role in the sociohistorical transformation of social spaces.

The paper is divided into four main parts. The first part highlights the English social housing context in which the study is set while the second part develops the theoretical frame for the study. It discusses neoliberalism and its conception as a process as well as highlighting the key concepts of Bourdieu's theory which are drawn upon. The third part gives a description of the methods adopted by the study. The final part discusses the process of neoliberalizing the English social housing field and how accounting is implicated in this. 


\section{Context}

In setting the context of the study, rather than attempt to summarize the history of the social housing sector in England prior to this point (for this see Malpass 1999, 2000, 2001, Mullins 2000, 2010; Manville et al., 2016) or review the history of neoliberal reform of this sector (for this see Mullins, 2000, 2010; Smyth, 2012; Manville et al., 2016) we focus on the period under investigation i.e. $2006-2016$.

The year 2006 was an important turning point in the social housing sector in England. In December 2006, the Labour government of Gordon Brown commissioned Professor Martin Cave to conduct a review of the regulation of social housing which was published in June 2007. The Cave Report recommended a single regulator for the social housing sector, the establishment of a regulatory framework and the adoption of co-regulation as the regulators approach to regulation of the sector (Cave, 2007). These recommendations were adopted by the government (via the Department for Communities and Local Government, DCLG) and came into force on 1 April 2010 with the single regulator being the Tenants Services Authority (TSA) and from 2012 the Homes and Communities Agency (HCA) (DCLG, 2010).

The initial regulatory framework was based on six standards (Tenant involvement and empowerment standard, Home standard, Tenancy standard, Neighbourhood and community standard, Value for money standard and Governance and financial viability standard) (TSA, 2010). The new regulatory framework also developed principles of co-regulation which included: (i) the responsibility for effective service delivery and meeting the regulatory standards lay with the HAs and not the regulatory system, (ii) HAs are accountable to their tenants, not to the regulator. Consequently, tenants must have the information and opportunities they need to hold HAs to account and to shape service delivery, (iii) HAs should make robust and honest self-assessments of their own performance, drawing on external validation (such as peer review and independent audits) as needed, and (iv) Regulatory intervention should be justified and proportionate (DCLG, 2010; TSA, 2010).

The May 2010 general election ushered in a Conservative/Liberal Democrat coalition government which unleashed an unprecedented drive to reduce deficits by introducing austerity policies. The austerity policies of the coalition government set in motion a radical re-orientation of housing policy in the UK and this has been accelerated by the majority Conservative Government elected in 2015 (Stephens and Stephenson, 2016). Hodkinson and Robbins (2013) argue that the cuts in government spending as a result of the austerity policies are being used as an ideological cover for a far-reaching, market-driven restructuring of social welfare policy that amounts to a return of class war conservatism. The policies of the coalition government impacted on social housing regulation in the form of a redesign of the regulatory framework in 2012 which saw the introduction of the rent standard as a seventh standard, changes to the existing standards, a categorisation of the standards as economic (Value for Money, Governance and Financial Viability, Rent) and consumer (Tenant involvement and empowerment standard, Home standard, Tenancy standard, Neighbourhood and community standard).

Another change was that the regulator focused on active regulation of the economic standard and lighter regulation of the consumer standards (HCA, 2012). The principles of co-regulation were also restated as: (i) Boards and councillors who govern HAs are responsible and accountable for delivering their organisation's social housing objectives, (ii) HAs must meet 
the regulatory standards, (iii) Transparency and accountability is central to co-regulation, (iv) Tenants should have opportunities to shape service delivery and to hold the responsible boards and councillors to account, (v) HAs should demonstrate that they understand the particular needs of their tenants, and (vi) Value for money goes to the heart of how providers ensure current and future delivery of their objectives (HCA, 2012).

While these changes to social housing regulation are self-evident, they present us with two challenges. First, how can we understand their neoliberal character and more importantly, how can we understand the role accounting played in these neoliberal reforms. It is to these then that the next three sections are addressed.

\section{From Neoliberalism to Neoliberalization}

"The need of a constantly expanding market for its products chases the bourgeoisie over the whole surface of the globe. It must nestle everywhere, settle everywhere, establish connections everywhere." (Marx and Engles, 2002, pp. 4)

Neoliberalism is everywhere. Indeed, Chomsky (1999) argues that it is a widely-believed chronology, on both sides of the ideological divide, that from the end of the 1970's neoliberalism conquered the world. But what exactly is neoliberalism? How is it defined? How do we know it when we encounter it? The dominant view of neoliberalism among critical scholars including critical accounting scholars is captured in Harvey's (2007, pp. 2-3) definition of neoliberalism:

"Neoliberalism is in the first instance a theory of political economic practices that proposes that human well-being can best be advanced by liberating individual entrepreneurial freedoms and skills within an institutional framework characterized by strong private property rights, free markets and free trade..... It holds that the social good will be maximized by maximizing the reach and frequency of market transactions, and it seeks to bring all human action into the domain of the market."

Neoliberalism is characterised by privatization (Arnold and Cooper, 1999; Cole and Cooper, 2006; Andrew, 2007; Parker, 2011; Jupe, 2009), marketization (Castree, 2010; Whitfield, 2006) and deregulation (Bourdieu, 1998b; Peck et al. 2010). Davies (2017) suggests that underpinning this view of neoliberalism is not so much a concern for the liberation and extension of markets but rather a focus on extending the reach of market-based principles and techniques of evaluation which are used to affect a "disenchantment of politics by economics". He argues that the defining characteristic of neoliberalism is its abandonment of the liberal conception of separate spheres of the economic, social and political and instead evaluating all three spheres according to a single economic logic. Thus, at its roots, the neoliberal theory is desocialised and dehistoricised (Bourdieu, 1998b). This conception of neoliberalism portrays it as a "thing" (Heynen and Robbins, 2005) or an "end-state" (England and Ward, 2007) and thus only permits for a binary or static comparison between past and present states. 
This dominant view of neoliberalism has been challenged by scholars in the fields of critical geography and politics. These scholars (Peck and Tickell, 2002; Tickell and Peck, 2003; Heynen and Robbins, 2005; Brenner et al. 2010a, 2010b) argue that we gain a richer understanding of the phenomenon by considering neoliberalization as a process rather than neoliberalism as a thing. Similarly, Brenner and Theodore (2002 pp 353) in their attempt to define neoliberalization argue that it must be construed as:

"a historically specific, ongoing, and internally contradictory process
of market-driven sociospatial transformation, rather than as a fully
actualized policy regime, ideological form, or regulatory framework."

Neoliberalization is historically specific in that its ideological and doctrinal roots can be traced to the classical liberal project of constructing 'self-regulating' markets in the late $19^{\text {th }}$ and early $20^{\text {th }}$ century (Brenner et al. 2010a) as well as to the works of Hayek and Ludwig Von Mises in the 1920s and 1930s (Davies, 2017). Its emergence and rise to dominance, if not hegemony, can also be traced to the era of Thatcher and Regan. It is ongoing in that it has established itself and remains the dominant discourse (Bourdieu 1998b) and ideology (Plehwe et al., 2007) of our age and continues to evolve and mutate, defying reports of its death in the heat of the 2008 financial crisis (Peck and Theodore, 2012) and demonstrating an ability to exploit the same crisis for its own mutation (Peck et al. 2010, 2012). The internal contradictions of neoliberalism are well documented in literature and include, structural contradictions (Crotty, 2000), the 'double movement' of deregulation and re-regulation (Polanyi, 1944; Mansfield, 2004; Tickell and Peck, 2003) and the creation of inequalities by liberalizing markets and driving competitiveness (Davies, 2017).

Viewing neoliberalization as a process transforms it from a static 'thing' to a dynamic interplay between agents, structures and objects which has a multiplicity of openings and closures (England and Ward, 2007). This process of market-driven transformation of society and space is hinged on regulatory restructuring which usually takes the form of regulatory experimentation and results in hybrid and unevenly developed regulatory systems (Brenner et al., 2010a). Indeed, several critical scholars (Foucault, 2008; Dardot and Laval, 2009; LeviFaur, 2009) suggest that the development and maintenance of free markets is not synonymous with a withdrawal of the state from economic affairs but rather that state intervention is a necessity for the growth and maintenance of markets. Levi-Faur (2009) argues that this increased state intervention in the form of 'regulatory capitalism' has led to experimentation with new forms of governance and regulation including co-regulation which he envisages as a system of regulation where responsibility for regulatory design or regulatory enforcement is shared by state and civil actors.

While it is possible to take the view that the introduction of the regulatory framework for the regulation of social housing in England is an ideologically neutral reform of the regulation of the social housing sector, the evidence points in a different direction. Cave's (2007) review of social housing regulation which proposed the introduction of the regulatory framework justifies the regulation of social housing on the lack of competitive pressures arising from an excess of demand for social housing over supply. DCLG's subsequent review of social housing regulation also gives a rational for the government's regulatory intervention in social housing thus: 
"The rationale for state intervention (through regulation) in the provision of social housing is based on:

i. $\quad$ The lack of competitive pressures towards good, efficient service provision; and

ii. The presence of substantial public subsidy.

There is also a specific factor that provides an additional reason for regulation: more than $\$ 40 b$ of private sector lending to housing associations has been made on the basis that they are regulated." (DCLG, 2010, pp. 4)

These show an ideological leaning to the neoliberal ideals of extending market-based principles of competitiveness, financial viability, governance and efficiency to underpin the new regulatory framework for social housing.

Taking this perspective of neoliberalization as a process opens up space for a dynamic analysis of the reform of social housing regulation in England focused on change. Indeed, Peck and Tickell (2002) argue that analysis of neoliberalism should focus on 'change - on shifts in systems and logics, dominant patterns of restructuring'. Such an analysis implies a departure from the macro (policy) level and micro (organisational) level analysis which has characterised critical research into neoliberalism to a more meso (industry) level analysis. It also implies shift away from the 'what' question to the 'how' question. For us then, the question moves away from 'what role did accounting play in neoliberalism?' to 'how is accounting implicated in the neoliberalization processes of the reform of social housing regulation in England?' - can we account for how accounting is mobilized and deployed in these neoliberalization processes? The next section explores the literature on the relationship between accounting and neoliberalization.

\section{Accounting, Society and Neoliberalization}

"Accounting has played a vital role in the development of modern society" (Hopwood, 1976 pp. 1) and yet our understanding of the intertwining of accounting and society is limited (Walker, 2016) as this area is under-researched (Hopwood, 1985; Walker, 2016). From research on accounting and society, we know that accounting is an instrument of social management and change (Burchell et al., 1985), serves as an ideological phenomenon which mystifies the nature of social relationships (Burchell et al., 1980), and is contextually situated (Gallohofer et al., 2015) both shaping and being shaped by the context in which it operates (Hopewood, 1983). Critical authors taking a political economy approach argue that accounting should be understood in the context of power and social relations characterised by class conflict (Cooper and Sherer, 1984; Tinker, 1980; Tinker et al., 1982). Indeed, Arnold (2009) explains that the political economy approach, rather than viewing accounting as a neutral and objective technology, views it as partisan and political, with accounting being influenced by ruling elites and dominant ideologies and in turn influencing the distribution of income, wealth and power within society.

Given the political nature of accounting and its ability to influence and be influenced by its social, economic and political context, we ask the question: "What do we know about 
accountings participation in the dominant ideology of neoliberalism?" Chiapello (2016) reviewing the critical accounting literature on neoliberalism identifies three broad ways in which the literature depicts accountings participation in neoliberalism. First, is the embedding of neoliberal ideas in accounting techniques such as fair value accounting (Zhang et al., 2012), public sector accrual accounting (Ellwood and Newberry, 2007), carbon tax (Andrew et al. 2010), as well as the accounting concepts of effectiveness, efficiency and value for money (Andrew and Cahill, 2016). These accounting techniques are diffused through organisational structures, state institutions and the accounting profession (Jackson and Lapsley, 2003) and serve as a means of naturalizing neoliberal forms of government (Andrew and Cahill, 2016).

Second, is the use of accounting techniques in neoliberal tests. Chiapello (2016) explains that 'tests' refer to 'any judgement systems or social arrangements organizing any testing of any entity's abilities, resulting in the ranking of tested entities by attributing worth' and refers to credit ratings as an example of a test (Fourcade and Healy, 2013). Thus, the accounting techniques which underpin these neoliberal tests serve as a basis for the allocation of duties, rights and power, and ultimately as a means of social control (Walker, 2016).

Third, is the involvement of accounting actors (practitioners and academics) in the development and promotion of neoliberal policies. While accountants and the accounting practice lay claim to objectivity and neutrality, several studies have implicated them in the development and diffusion of neoliberal policies (Jackson and Lapsley, 2003; Jupe and Funnell, 2015; Zhang and Andrew, 2014). The role of accounting academics in advancing neoliberal ideas is noted by Tinker et al. (1982) who argues that accounting academics have contributed, by way of accounting theories, some of the more sophisticated 'masks' used to mystify the socially partisan role accounting plays as these theories elevate accountings technical, factual and seemingly objective aspects.

While these studies enhance our understanding of 'what' accounting does in relation to neoliberalism, they leave us in the dark as to 'how' accounting is deployed to achieve these ends and what is done in the name of accounting (Hopwood, 1994). In order to open up this 'black box' of accountings involvement in the neoliberalization process and develop our understanding in this area, we argue that we must orient towards process and practice theory. In making sense of the neoliberalization processes, we would like to suggest that Bourdieu's $(1977,1984 a, 1986,1990,2005)$ notions of field, capital and habitus are particularly helpful because they provide us with a way of conceptualizing the role of accounting in the neoliberalization processes. We explore these notions of field, capital and habitus in the next section.

\section{Bourdieu's System of Thought}

French sociologist, Pierre Bourdieu, regarded as one of the most influential figures of the twentieth century (Yang, 2014) develops a framework to account for the dynamics of power in society - how power is transferred and social order maintained within and across generations - which integrate a theory of social structures (field), a theory of power relations (forms of capital), and a theory of the individual (habitus) (Dobbin, 2008; Malsch et al., 2011; Stringfellow et al., 2015). His theories have been applied by studies seeking to adopt processual 
or practice based perspectives and account for dynamics of social change (Kitchin and Howe, 2014; Wright, 2009; Grenfell and James, 2004).

Bourdieu conceptualises all social spaces as fields (Bourdieu and Wacquant, 1992) for example economic, political, cultural and educational fields. These fields may be further divided into narrower fields e.g. the economic field may include the housing, manufacturing, banking, and retail fields which may be further narrowed to include firms, regulators, etc (Bourdieu, 2005). He defines a field as:

"a network, or configuration, of objective relations between positions. These positions are objectively defined, in their existence and in the determinations they impose upon their occupants, agents or institutions, by their present and potential situation (situs) in the structure of the distribution of species of power (or capital) whose possession commands access to specific profits that are at stake in the field, as well as by their objective relation to other positions (domination, subordination, homology, etc.)." (Bourdieu and Wacquant, 1992. pp. 97)

A field is conceptualised as a configuration of relations between at least two positions which are occupied by actors (organisations or individuals) and constitute a structure or temporary state of power relations. Indeed, the field is not a level playing ground ( $\mathrm{Xu}$ and $\mathrm{Xu}, 2008)$ as actors occupy different positions which are determined by the power, resources and capital which they possess. Consequently, fields are understood as sites of struggle (Madsen and Dezalay, 2002) where actors struggle and manoeuvre to gain monopoly over resources, power and capital which are at stake in the field and thus gain domination over the field (Emirbayer and Johnson, 2008; Malsch et al. 2011). The struggles within the field are influenced, in part, by symbolic violence which denotes more than violence operating symbolically but rather 'the violence which is exercised upon a social agent with his or her complicity' (Bourdieu and Wacquant 1992, pp. 167). It serves to create order through constraint (Bourdieu and Wacquant, 1992) but at the same time obscures the power relations which underpin it through the disguise of legitimacy (Jenkins, 2002, Gracia and Oats, 2012).

While the struggles in the field tend towards a reproduction of the game, Bourdieu (1992 pp. 99) notes that actors can also get in 'to transform, partially or completely, the immanent rules of the game'. Thus, Bourdieu acknowledges that the construction of the field, far from being static is open to constant change as actors struggle within the field.

Bourdieu $(1986,1977)$ views capital as a wide range of resources (economic, social, cultural or symbolic) which are valuable within a field. Each type of capital manifests in a different form and 'has a different degree of liquidity, convertibility and susceptibility to attrition' (Everett, 2002, p. 64). The positions of actors in the field is determined by the nature and quantity of capital they possess as two actors possessing the same overall quantity of capital will differ in their positions as a result of the differing nature or composition (economic, social, cultural or symbolic) of the capital which they possess. Indeed, Bourdieu and Wacquant (1992. pp. 101) explain that:

"capital does not exist and function except in relation to a field. It confers a power over the field, over the materialized or embodied 
instruments of production or reproduction whose distribution constitutes the very structure of the field, and over the regularities and the rules which define the ordinary functioning of the field".

The state is conceptualized as an entity which plays in all fields and represents a concentration of the different species of capital (Xu and $\mathrm{Xu}, 2008$ ). Bourdieu notes:

"there has occurred, since the construction of the dynastic state and, later, the bureaucratic state, a long-term process of concentration of different species of power, or capital, leading in the first stage to private monopolization - by the king - of a public authority at once external and superior to all private authorities...the concentration of these different species of capital - economic (thanks to taxation), military, cultural, juridical and, more generally, symbolic - goes hand in hand with the rise and consolidation of the various corresponding fields. The result of this process is the emergence of a specific capital, properly statist capital, born of their cumulation, which allows the state to wield a power over the different fields and over the various forms of capital that circulate in them." (Bourdieu and Wacquant (1992. pp. 104

State intervention in any field inevitably redefines the distribution of capital and power relations in that field. Thus, actors in the field try to interact with the state by competing for influence over the state and its polices $(\mathrm{Xu}$ and $\mathrm{Xu}, 2008)$. Bourdieu highlights this aspect of the "state" as an ensemble of administrative and bureaucratic fields which take the form of departments, commissions, boards etc. He argues that these fields are the sites of struggles aimed at gaining a "monopoly of legitimate symbolic violence" which he explains to mean the power to impose a common set of coercive norms as "universal and universally applicable" within its boundaries (Bourdieu and Wacquant, 1992, pp 112).

Drawing on Bourdieu's view of the state both as an ensemble of fields and as a player within the fields, we conceptualize the social housing regulatory space in England as the field of our study and the social housing regulator as being a player representing the state in that field. Other players in the field include housing associations, local councils, tenants and tenant organisations, housing consultants, lenders, industry associations (e.g. National Housing Federation $[\mathrm{NHF}]$ ) and other stakeholders.

The third concept in the Bourdieusian triad is habitus. It is arguably the most used, abused and contested of the triad. Habitus operates as the mechanism which embeds social structures into the agent and is defined as a "system of durable, transposable dispositions, structured structures predisposed to function as structuring structures" (Bourdieu, 1977). Bourdieu describes it as the "feel for the game" which is played in the field (1990) and uses it to symbolise the structure of the game itself. Habitus determines an agent's (individual or group) actions in any given situation and is formed primarily through a lifetime of unconscious inculcation and socialization (Malsch et al. 2011). However, habitus can be formed through a secondary means of "methodical inculcation" (Bourdieu and Passeron, 1977, p.47) which is more articulated and formalized. While habitus has traditionally been conceived as fixed, Bourdieu highlights its dynamic nature when he explains: 
"Habitus is not the fate that some people read into it. Being the product of history, it is an open system of dispositions that is constantly subjected to experiences, and therefore constantly affected by them in a way that either reinforces or modifies its structures. It is durable but not eternal!" (Bourdieu and Wacquant, 1992, pp. 133)

Bourdieu uses the analogy of a game to give an intuitive understanding of his concepts and how they are interrelated and interpenetrating thus:

"we can indeed, with caution, compare a field to a game....we can picture each player as having in front of her a pile of tokens of different colors, each color corresponding to a given species of capital she holds, so that her relative force in the game, her position in the space of play, and also her strategic orientation towards the game, what we call in French her 'game' the moves that she makes, more or less risky or cautious, subversive or conservative, depend both on the total number of tokens and on the composition of the pile of tokens she retains, that is on the volume and structure of her capital..... to be more precise, the strategies of a 'player' and everything that defines his 'game' are a function not only of the volume and structure of his capital at the moment under consideration and of the game of chances they guarantee him, but also of the evolution over time of the volume and structure of this capital, that is this social trajectory and of the dispositions (habitus) constituted in the prolonged relation to a definite distribution of objective chances." (Bourdieu and Wacquant, 1992, pp. 98-99)

Bourdieu's system of thought has been profoundly influential across the social sciences (Stringfellow, 2015; Maclean et al. 2012; Emirbayer and Johnson, 2008) and has been used significantly within the critical accounting literature (Kuruppu et al., 2016; Stringfellow, 2015; Cooper and Coulson, 2014; Spence and Carter, 2014; Cooper et al. 2011; Golsorkhi et al. 2009). Most of the accounting literature which draw on Bourdieu's theories use single concepts (field, capital or habitus) as opposed to deploying his oeuvre. These single concepts are usually used in an analysis of systems of domination and how these are reproduced. Even where all Bourdieu's concepts are deployed, the focus has still rested on their ability to illuminate systems of domination and their reproduction (Golsorkhi et al. 2009). Indeed, one of the major criticisms of Bourdieu's theories is their inability to anticipate change (Yang, 2014). Bourdieu strongly rejects the criticism of determinism, arguing that this criticism is based on a superficial and partial acquaintance with his total oeuvre (Bourdieu and Wacquant, 1992).

A careful reading highlights that the theme of reproduction is especially prominent in Bourdieu's works on class, culture, and education in France particularly Reproduction (1977) and Distinction (1984), Outline of a Theory of Practice (1977) and The Logic of Practice (1990). The theme of transformation, on the other hand, is evident in his works such as The Algerians (1962), The Bachelors' Ball (2008), The Rules of Art (1996a), Homo Academicus (1984b), The State Nobility (1996b) and The Political Ontology of Martin Heidegger (1991). These highlight the interrelationships between his concepts of field, habitus and capital and the fact that they all vary over time. Change, therefore, is a necessary consequence of Bourdieu's 
conception of habitus and field as being interrelated and interpenetrating, so that a change in one necessitates a change in the other (Grenfell, 2014).

Indeed, amongst scholars who deploy Bourdieu's total oeuvre there is a recognition that Bourdieu's theories are at once about reproduction as they are about transformation and thus provide a valuable lens through which to analyse sociohistorical change. Gorski (2013 pp 12) argues thus:

"Careful readers of Bourdieu's work have long recognized that his conceptual framework can be used to study sociohistorical transformation.... That said, it would be silly to argue that Bourdieu was not also a reproduction theorist or to deny that reproduction was a major theme in his work. He was both - a theorist of reproduction and a theorist of transformation - as any student of society and history should be. What are the historical and social sciences, after all, if not sciences of continuity and change? Indeed, I would argue that one of the advantages of the Bourdieusian framework is that it allows one to analyze social reproduction and transformation and historical continuity and rupture, even simultaneously."

It is in this light that we adopt Pierre Bourdieu's concepts of field, capital and habitus as a lens to conceptualize the neoliberal reform of social housing regulation in England, enabling us account for concomitant processes of transformation and the reproduction of power relations. Anderson et al. (2010) suggest that there are two ways we can employ such concepts. First is as a sensitizing device to identify areas of interest and second is as a structuring device to make sense of things. We use these concepts in both ways - first sensitising our approach to the data and second as a means of structuring and making sense of things.

\section{Methods}

Mindful of the fact that we draw on Bourdieu's theory to sensitise and structure our empirical work, we also turned to his thoughts for guidance on methodology. Bourdieu (1998a pp.2) explains that in order to understand the logic of the social world, one must plunge 'into the particularity of an empirical reality, historically located and dated, but with the objective of constructing it as a "special case of what is possible".'. This approach has been adopted by critical accounting scholars (see for instance Cooper et al., 2011). We locate this study in the most recent period of neoliberal reform of social housing regulation in England which spanned from 2006 to 2016 and identify the object of this study as the role of accounting in creation and implementation of the co-regulatory system in social housing regulation and we try to answer the research question:

How is accounting implicated in the process of introducing the new regulatory framework for social housing in England?

In relation to techniques of data collection and analysis, Bourdieu encourages flexibility and polytheism thus:

"We must try, in every case, to mobilize all the techniques that are relevant and practically usable, given the definition of the object and 
the practical conditions of data collection....the long and the short of it is, social research is something much too serious and too difficult for us to allow ourselves to mistake scientific rigidity, which is the nemesis of intelligence and invention, for scientific rigor, and thus to deprive ourselves of this or that resource available in the full panoply of intellectual traditions of our discipline and of the sister disciplines of anthropology, economics, history, etc. in such matters, I would be tempted to say that only one rule applies: "it is forbidden to forbid". ", (Bourdieu and Wacquant, 1992, pp. 227)

Thus, in creating the "special case", we drew on several consultation documents and responses, industry surveys and reports, regulatory reviews, regulatory frameworks, HA self-assessment reports, Regulatory judgements and social housing press reports which are detailed in Appendices 2 and 3. We adopt a four-stage approach to analysing the data. First, we specified the focus of our analysis with reference to the research question. Thus, we specified the analytic focus as: the role of accounting in the process of introducing the new regulatory framework for social housing in England. This enabled us to determine what data was relevant and what could be discarded. The next stage involved a search for patterns in the data. Here the data was reviewed iteratively with us constantly asking ourselves what was happening here? The iterative cycle of reading, reflecting, re-reading the documents enabled us develop familiarity with the data and develop a stream of reflective notes.

The third stage used the constant comparison method of analysis (Jack et al. 2010; Jack and Anderson 2002; Anderson and Jack, 2002; Anderson 2000b) and Analytic induction (Cressey 1953; Robinson 1951; Katz, 2001) to aid the development of categories and concepts. The constant comparison method of analysis consists of two main activities: fragmentation and comparison (Boeije 2002). Fragmentation was achieved through the open coding of individual documents. This allowed us to lift the coded piece out of the context of the whole document / notes. Comparison was performed at various levels e.g. within documents, between documents, within emergent categories and themes, between emergent categories and themes. This process of constantly fragmenting and comparing allowed for themes and categories to emerge and be refined as the study progressed. Analytic induction (Cressey 1953; Robinson 1951; Katz, 2001) involved the initial inspection of a few documents to locate common factors and provisional explanations. As new documents were examined and initial conclusions were contradicted, the explanations were refined by redefining the phenomenon to be explained to exclude the contradictory case and/or redefining the explanatory factors (Cressey 1953; Robinson 1951).

The fourth stage of the analysis process was the development of an explanatory frame. This involved iterations between the data supporting the categories and concepts developed and Bourdieu's theory of practice. This iteration enabled the development and continuous refinement of the explanatory frame. As the iterations between data and theory continued, elements of the frame were retained, revised, removed or added. This iteration also enabled us to refine categories and concepts earlier developed and to develop an account of how accounting is implicated in the neoliberal reform of social housing regulation. We present this account in the next section. 


\section{An Anatomy of Reproduction and Transformation Processes}

We found that in the process of introducing the new regulatory framework for social housing, accounting was used at times as a means of reproducing the game played in the field and at other times as a means of transforming the game. We frame the discussion of accounting's role in reproducing and transforming the game under four thematic heads which emerged from the analysis of the data. These are: accounting as a means of achieving social control; empowering and disenfranchising tenants; decoupling performance from social impact; and driving organisational change.

\subsection{Accounting as a means of achieving social control}

Two key components of the 2010 reform of social housing regulation in England were the introduction of a regulatory framework and the creation of the HCA as the new regulator for social housing. Conceptually, these could be explained by Bourdieu's account of the field and the state's power to intervene in any field born out of its cumulation of statist capital. Indeed, the creation of the HCA and the introduction of a regulatory framework are in fact the instances of the state intervening in the social housing field to introduce a new actor (HCA) and to change the structures of the field. These two are intertwined as the HCA helps entrench the new structures while the new structures help institutionalise the HCA as the dominant actor in the field by enabling it gain social control over other actors in the field. Let us explain, and in doing so, try to uncover what role accounting played in this process.

The regulatory framework for social housing in England outlines six principles of co-regulation and seven regulatory standards. What these do is create norms or ideal standards of behaviour which are universally applicable to HAs. In defining these norms or ideal standards of behaviour, the HCA mobilizes accounting in the form of accounting concepts which are in common usage in both the private and public sector. Table 1 below gives a summary of these concepts and how they are deployed:

Table $1 \quad$ Accounting Concepts and their deployment

xxx Insert Table 1 here $\operatorname{xxxxx}$

Derived from HCA (2012)

While some of the accounting concepts deployed in creating these norms and behavioural ideals are ambiguous and contested, they are nonetheless useful in giving concrete form and an appearance of objectivity, neutrality, familiarity and, therefore naturalizing these norms of behaviour in the field. In participating in the creation and definition of what is acceptable behaviour in the field, accounting is implicated in defining and locating deviance as behaviour which falls short of, or is at variance with, the defined norms. Importantly, also, the use of accounting concepts in creating these norms and behavioural ideals ensures that it is an economic logic which is used to define what good or bad behaviour looks like. 
In addition to creating the norms and thus defining what is acceptable and deviant behaviour, accounting is implicated as a mechanism of social control in three ways. First, it has what we term as a carrot and stick effect. In this case, the HAs provide accounts of their performance against the norms and standards to the HCA through value for money self-assessments, annual reports and annual statistical returns, etc. Once this information is amassed by the HCA, it makes the HAs visible and governable as the HCA now has the information it needs to base its decisions and interventions on. Thus, the HCA is able to discipline, punish, rehabilitate or empower the HAs based on the accounting information which it receives. We illustrate this by highlighting the HCA's mobilization of accounting in giving a rational for its regulatory judgement downgrading the financial viability ratings of a HA in July 2015 :

"The regulator's assessment of Abbeyfield's financial viability has
been downgraded. Whilst the provider does not have current liquidity
issues, from evidence gained through contact with the executive and a
review of the latest financial forecasts, annual accounts and the
quarterly surveys, the regulator has identified specific risk exposures
that could potentially impact on Abbeyfield's viability if not adequately
managed" (Regulatory Judgement H1046)

Second, is the constraining effect of accounting. By this we mean that the account of itself which the HA creates and delivers up to the HCA and other stakeholders, to aid their decision making, itself constrains the HA as the HA would like to present a 'good' account of itself and not a 'bad' one. This is the case as a 'good' account of itself enhances its reputation and enables it accumulate reputational capital (a form of symbolic capital) and thus strengthen its position within the field. A 'bad' account on the other hand has the opposite effect. The case of the Together Housing Group (THG) ${ }^{3}$ is illustrative of this. The THG created a 'bad' account of itself as it engaged with regulators and other stakeholders. This 'bad' account depreciated its capital stock in the eyes of the regulator and other stakeholders and ultimately led to a weakening of its position in the field by a regulatory governance downgrade as well as a downgrade of its credit rating by Moody's. The HCA indicated that the downgrade was as a result of a lack of assurance on its control system as well as the inaccuracy and untimeliness of its financial controls while Moody's indicated uncertainty related to governance changes and evidenced by the posting of lower margins than budgeted over two financial years. The downgrade by the HCA was carried by Inside Housing, the most widely read social housing news publication under the headline "Inaccurate financial reporting sees landlord downgraded by HCA" (Inside Housing, 2017) further damaging THG's reputation and thus its stock of reputational (symbolic) capital.

The third way in which accounting is implicated as a mechanism for social control is its role in embedding the social structures through which social control is exercised. The mobilizing of accounting concepts in the regulatory standards through which the HCA exercises control over the HAs constrains the HAs determination of what accounting data to be recorded, its extent and the methods used in collecting such data. This reinforces dominant neoliberal

\footnotetext{
3 THG owns and manages 38,026 homes for rent, shared ownership and sale across the North of England. It employs 1,145 staff who provide housing related services and support to its over 40,000 residents. (THG, 2017)
} 
ideology as well as reinforces the nature of power relations between the HCA as the data gatherer and the HAs as the data suppliers.

From a Bourdieusian perspective, these change processes can be understood as consisting of two simultaneous and intertwined movements. The first movement is a transformation of the field by the introduction of a new actor, the HCA, imbued with the power of the state and its statist capital onto the field as well as the modification of the rules of the game by the introduction of the new regulatory framework steeped in the neoliberal economic logic. These changed the structure of the field and the nature of the struggles which occurred on it. The second movement is the establishment and reproduction of the system of domination on the field evidenced by the HCA's use of the new regulatory framework to gain social control over other actors in the field and establish itself as the dominant actor in the field. Far from being neutral, accounting is implicated as an active and partisan tool in both movements.

\subsection{Accounting as a means of empowering and disenfranchising}

In addition to being implicated in norm creation and gaining of social control, we find that the use of accounting concepts such as transparency, accountability and value for money in the structuring of the regulatory framework for social housing has led to a redefinition of power relations and distribution of capital and resources within the field. Indeed, the ambiguity in and contestation of the meaning of these concepts, has allowed successive governments to impose their ideological stance on the field. Thus, in turn empowering and/or disenfranchising actors in the field of play. We illustrate using the value for money concept and its operationalization through the value for money standard. Table 2 shows how the Labour government in 2010 defined and operationalized value for money and how this changed when the Conservative/Liberal Democrat coalition government reviewed the social housing regulatory standards in 2012.

Table 2

Value for Money

xxxx Insert Table 2 here $x x x x$

Derived from TSA $(2009,2012)$

The consultation questions in the statutory consultations under the Labour government used in developing the value for money standards show a focus by the Labour government on the interests of tenants and thus an empowering of the tenants in the wording of the value for money standard produced and operationalized at the end of the consultations. The consultation questions under the coalition government, however, prioritise the interests of the taxpayer and thus the state/regulator at the expense of the tenants. This in effect redefines the power relations in the field. It disenfranchises the tenants and puts the HAs and the regulator (HCA) in dominant positions in relation to the tenant. This violence enacted against the tenants through the redefining of the way value for money is conceived and operationalized was met by some feeble opposition from tenant representative bodies who had already been weakened by the abolishing by the coalition government in July 2010 of the National Tenant Voice which was the main vehicle for tenant advocacy. The response by the two tenant representative 
organisations who submitted responses to the consultation are instructive and highlighted below:

"Tenants and Resident Organisations of England (TAROE) believes tenants should be at the centre of value for money studies to ensure landlords focus on what really matters to improving services" (TAROE, 2012)

"We consider the standard is weakened by the failure to stress the importance of tenant involvement in delivering value for money." (Tenant Participation Advisory Service [TPAS] 2012)

These responses are very short when compared with the length of responses by other organisations on issues which they considered important. TAROE give the rational for such short responses to the consultation on a matter which goes to the very core of its existence the advocacy for tenants' rights:

"I am writing on behalf of TAROE in response to the consultation document. This response is short. This is because TAROE is fully aware that the present Government's aim has been to reduce consumer regulation and to ensure that the Regulator focus on financial matters. TAROE strongly believes this will put tenants at a great disadvantage and at the mercy of poor performing landlords. Tenants will not now have a Regulator who takes the health and well being of tenants as a central core of its business. This is not the fault of the TSA (or HCA); its Board or staff since as a Government Agency the TSA (HCA) are duty bound to carry out the Government's directions." (TAROE, 2012)

Thus, the narrative presented by the state (dominant actor in the field) that the shift in focus away from the tenants is inevitable is shown to influence the tenant body's adoption of a fatalistic worldview which renders them ineffective in their role of advocating for tenants' rights. This represents an enactment of symbolic violence by the state in which accounting is complicit.

Again, Bourdieu's concept of field as well as that of cumulated statist capital empowering the state to intervene in all fields provides us with a more conceptual explanation of the change processes described above as well as accounting's role in them. Indeed, the state is shown to intervene in the social housing field by changing the meanings attributed to accounting concepts used in norm creation in a bid to transform the structure of the field in terms of power relations and relative positions of actors on the field. The meanings attributed to the accounting concepts are dependent on the political leaning of the actors who control the state (conceived as an ensemble of fields) and have the effect of redefining the power relations and relative positions of tenants, the HCA and HA's on the field. Thus accounting is shown to be partisan and ready to dance to the tune played by the dominant actor in the field. This transformation of the field, while peaceful in the sense that it does not engender any physical violence, is symbolically violent as it depends on the deployment of the immense power of the state to intervene in the social housing field. This deployment is so forceful that it places the tenants in a dominated position, stifles their voice and cowers them into acquiescing to the changes.

\subsection{Accounting as a means of decoupling performance from social impact}


A key aspect of the regulatory reform of social housing in England was the HCAs approach to regulation of the sector. This new approach to regulation significantly impacted on the way the 'game' was understood and played by the actors on the field.

The 2012 regulatory framework separates the economic standards (value for money, rent, financial viability and governance) from the consumer standards (Tenant involvement and empowerment standard, Home standard, Tenancy standard, Neighbourhood and community standard). Thus it decouples economic performance from service provision, and therefore, effectiveness and social impact. It sets up two alternative logics in the field i.e. an economic and a social logic. This dichotomy is further entrenched by the HCA's approach to focusing its efforts more on regulating the economic standards. Indeed, this approach, neoliberal in character, sets up the economic logic as the dominant logic in the field. TPAS in its response to the consultation on changes to the regulatory framework makes the point:

\section{"The separation of the standards into economic ones and consumer ones and the related down-playing of the importance of tenant involvement is, in our view, false economy and risks missing the lessons of the last twenty years. " (TPAS, 2012)}

These thoughts were also echoed by TAROE (2012) as shown in the previous section. Thus, the players in the field are well aware of the regulators interest in the economic standards, its disinterest or indifference to the consumer standards and the role and rights of tenants. Cognisant of these, the HAs mobilize accounting techniques and practices to prepare their returns to the regulator (value for money self-assessment, annual reports, statistical returns) in such a way as to satisfy the regulator that the economic standards are being met. If they are successful in doing this, they gain symbolic capital in form of enhanced reputation in the eyes of the regulator and thus improved regulatory ratings. In addition to this, the regulator is less inclined to pay regulatory attention to them. The HCA summarizes its approach to regulation thus:

"The regulator's assessment on compliance with the Governance \& Financial Viability standard is expressed in gradings from G1 to G4 for governance and V1 to V4 for viability. For both viability and governance the first two grades indicate compliance with the standard. A G3 or V3 assessment indicates a level of concern with the organisation's performance that is likely to be reflected in intensive regulatory engagement. A G4 or V4 judgement indicates a more serious failure of governance or viability leading to either intensive regulatory engagement or the use of enforcement powers." (Regulatory Judgement LH0269)

Thus, the HA's ability to mobilize accounting techniques and practices effectively to demonstrate to the regulator that it meets the economic standards results in its legitimizing and strengthening its position in the field as well as an avoidance of 'intensive regulatory engagement'. In effect, so long as high grades are obtained for governance and financial viability (economic performance), the HA's quality of service delivery to tenants (social performance) is free from 'intense scrutiny'. This combined with the lower level of regulation of consumer standards allows the HAs to uncouple its actions from the accounts which are made of them. It then gains the freedom to be unaccountable to its tenants and other 
stakeholders in relation to achieving its social objectives. This ability to decouple performance from social impact is highlighted when we analyse the value for money self-assessments of HAs. We illustrate this by contrasting the approaches to value for money of two HAs:

"Value for money is all about getting the right balance between the cost of delivering our services and how efficient and effective we are as an organisation. It's not just about saving money - it's about getting the most for our money. So, when we talk about our value for money achievements on pages 12 and 13, we are not just looking at the cost savings - we are also looking at qualitative improvements and the social impact." (Acclaim Housing Group [AHG], 2014)

"Our value for money Approach: The Board and executive has a clear value for money vision to challenge and transform our operations. By creating income streams through a commercial agenda and driving efficiency through strong ICT investment to support channel shift and customer self-service, in order to reduce our costs and overheads. Our Corporate Plan 2015-2020 and Value for Money Strategy agreed in October 2014 has 5 clear objectives: 1. Scrutinising and challenging our services 2. Buying or providing services which drive down cost and improve quality 3. Collecting rents and service charges effectively and efficiently to pay for housing services 4. Managing our assets effectively 5. Creating efficient and accessible services through new Information and Communications Technology" (Gloucester City Homes [GCH], 2016)

The first, (AHG) shows a balance between the pursuit of efficiency, economy and social impact while the second, $(\mathrm{GCH})$ shows a bias towards efficiency and economy. Both HAs hold the highest regulatory rankings for governance (G1) and financial viability (V1) although AHG has focused on both economic performance and social impact while GCH has focused mainly on economic performance and is thus able to decouple itself from achieving social impact.

Bourdieu's conception of field and habitus as being interrelated and interpenetrating, such that a change in one necessitates a change in the other, enables us explain the events described above. The changes to the structure of the field in terms of rules, players, power relations and positions on the field noted in previous sections necessitate a change in the habitus which symbolises the structure of the game itself. The HCA signals this with its new approach to regulation which, intentionally or not, emphasises a new set of values and logics in the field i.e. economic values and logic as opposed to social values and logic. The HAs thus have to adapt their understanding of the game and the manner in which they play the game. For some HAs, they stay close to their current values while others seize the opportunity presented to adapt their values. They use accounting as a tool to demonstrate their acquisition of these new set of values and in so doing are able to break away from their old habitus. They are able to highlight economic performance and cast off the 'burden' of achieving social impact. This change in the habitus reinforces the positions of the HCA, HAs and tenants on the field as well as the power relationships between them, thus at once transforming the game and reproducing the transformed game. 


\subsection{Accounting as a means of driving organisational change}

In addition to being implicated in the changes to the structure and habitus of the social housing field, we find that accounting is also implicated in the changing structure and habitus of the HA sub-fields. We provide evidence of this by discussing the changes in terms of board composition and organisational culture which are occurring within HAs across England.

The introduction of co-regulation along with the regulatory standards in 2010 significantly increased the responsibilities placed on the Boards of HAs. These responsibilities were further amplified in 2012 with changes to the value for money standard requiring the Boards to 'articulate and deliver a comprehensive and strategic approach to achieving value for money' and publish an annual self-assessment of how they are delivering value for money (HCA, 2012) as well as a new regulatory focus on regulating the economic standards and the HCAs drive to 'professionalise' boards and executive management teams. An industry analyst comments on this thus:

"the HCA places continued and additional focus on HAs having the
appropriate skills, expertise and experience on executive teams and
boards, with the latter able to challenge their executives as well as their
own effectiveness, as well as their abilities to show value for money."
(Cowley, 2014)

With this move away from volunteer board members without 'appropriate skills, expertise and experience' but with an interest in the social objectives of the business to a more 'professional' board and executive team, the power relations within the organisational field are changing. The boards are now in a more powerful position as they have a greater stock of cultural capital (expertise and experience), and thus, are less likely to be dominated by the executive team. A 2016 Inside Housing survey of HA board members presents a second dimension to the change of actors in the field. It finds that board members with financial skills were the second largest segment of board members. Its analysis of the survey report notes:

"Financial skills are also much in evidence on boards, at various levels, perhaps brought in as the sector tries to become more commercial. In the age of 'value for money' and the 1\% annual rent cut, it is no surprise that boards court members with financial experience." (Inside Housing, 2016)

This privileging of financial skills on boards as a result of the increased focus on regulation of the economic standards implicates accounting in the changing patterns of organisational influence and control.

In addition to driving change in actors and power relations at the organisational level field, the HCA and its regulatory framework and approach is driving change in the organisational level habitus in two broad ways. First, the nature of the relationship between the HA and its board is changing. As HAs are demanding board members with certain expertise and experience they are having to move away from seeking for volunteers for their boards to actively recruiting and paying professionals with the expertise and experience they require. Notably, an NHF survey in 2009 (before the regulatory framework was introduced) showed that $35 \%$ of HAs paid their boards, this number rose to 52\% in 2014 (Brown, 2014) and now stands at 87\% (Grant Thornton, 2016). This move to paying board members introduces a contractual approach to 
relationships between the board and organisation as opposed to the 'gentleman's agreement' which existed previously. This also changes the boards approach from one focused on the social objectives of the HAs to a more business-like approach focused on discharging its regulatory obligations.

Second, the requirement for the board to 'articulate and deliver' a value for money strategy which achieves "continuous improvement in their performance on running costs and the use of their assets." (HCA, 2012) is compelling HAs to embed value for money in all aspects of their operations. We illustrate how this is being done and its impact on organisational habitus with quotes from value for money self-assessments of three HAs in Table 3.

Table 3 Embedding value for money

xxxxx Insert Table 3 here xxxxx

The embedding of value for money in the organisations culture, operations, planning, control and decision making is in effect creating a new set of dispositions and structures which will be concretised and transmitted over time within the organisation. Thus, redefining the organisations habitus.

\subsection{Summary}

Through our evidence and analysis, we have endeavoured to show how accounting is implicated in the creation and reproduction of systems of domination in the English social housing field. We showed that accounting does this by enabling the housing regulator achieve social control over other players in the field. Accounting concepts introduce an economic logic which is used in the creation of norms which at once define standards of acceptable behaviour as well as deviance. Thus, accounting influences the 'rules of the game' which are played in the housing regulatory field. It is also implicated in the struggles for power and capital which take place in the field as the HAs use accounting as a tool to present a favourable account of themselves. Accounting used in this way constrains their behaviour while making them visible to, and governable by, the regulator. This presentation of accounts also legitimises the regulator as the dominant player in the field, gathering information and disbursing rewards and punishments as it deems fit. Indeed, it aids in both the entrenchment and reproduction of the power relations in the field.

Accounting is also shown to be implicated in the transformation of the social housing regulatory field in three ways. First, the change in the way the accounting concept of value for money was defined is shown to impact on the power relations within the field. When, value for money was defined in terms of value for the tenant's money, it put power in the hands of the tenant and thus in a dominant position in relation to HAs. However, when value for money was redefined in terms of value for taxpayer's money, it took this power away from tenant's and thus they lost both their dominant position in relation to HAs and their 'voice' on the field. Indeed, accounting is shown in this case to be politically and ideologically partisan and thus, not neutral in its effects. Second, the HCAs approach to emphasising the regulation of the 
economic standards to the exclusion of the consumer standards allows the HAs to decouple financial performance from social performance and impact. Thus, so long as the HAs meet their duties to account for economic performance to the dominant player in the field i.e. the regulator, they are given the liberty to become unaccountable to other players in the field to whom they had hitherto been accountable. Third, the HCAs approach of putting the accounting concept of value for money at the heart of its regulatory approach has led to a change in both the habitus within individual HAs and the wider field of social housing. HAs have moved from having volunteer boards to having professional boards who are better able to cope with the increasingly complex demands of running HAs. The demand for finance related skills on these boards have increased, thus changing the composition of the boards. Organisational culture within the HAs is also changing as they seek to embed value for money within their organisations.

\section{Discussion}

We set out to account for the role accounting played in the neolibralization processes of reforming social housing regulation in England. In doing this, we deployed Bourdieu's concepts of field, capital and habitus as a theoretic lens through which to view this sociohistorical process of reproduction and transformation. While not without its limitations, this approach enabled us develop multiple insights which we now discuss in turn.

First, adoption of a Bourdieusian perspective enabled us develop an understanding of the process through which neoliberalism takes hold within a field which we illustrate in Figure 1 below.

\section{Figure $1 \quad$ Neoliberalization process}

\section{Xxxx Insert Figure 1 here $x x x x x$}

The process is instigated by the state. Driven by a neoliberal ideology which seeks to impose an economic logic on all fields, the state uses its immense power to intervene in the field forcing a transformation in the structure of the field in terms of norms, power relations and actors on the field. This change in the structure of the field is naturalised by, as well as drives change in, the field level habitus in terms of a privileging of the economic logic over the social logic. Players in the field seeing an opportunity to enhance their position adapt their game to privilege economic logic over social logic. The changes to the structure of the field and its habitus also drive changes in the structure and habitus of the sub-fields as the sub-fields seek to adapt to the changing field in which they exist. Taken together, these changes transform the field and redefine the game that is played in it to become one based on economic logic. Crucially also, they enable the redefined game to settle and be reproduced over time.

In addition to developing an understanding of the neoliberalization process in the social housing field, by deploying Bourdieu's concepts we gain insight into how it is that the tenants have moved from being in a dominant position in the field to that of being the dominated by both the HCA and the HAs. Indeed, we see that the domination of the tenants resulted not from gradual changes to the field over time but rather from interventions of the state and its actor on the field (HCA) deliberately targeted at strengthening the HCA and HAs and at the same time weakening the tenants position and power on the field. 
Bourdieu's concepts also enable us develop insights as to what role accounting played in this process. Indeed, we see accounting deployed as a tool by the state and other players in the field in creating, transforming and reproducing the game. The state deployed accounting in support of its intervention in the field to emphasise the economic logic over the social logic in terms of creating new norms, empowering or disenfranchising players so as to redefine power relations on the field as well as in establishing the state actor (HCA) as the dominant player in the field. The HAs used accounting to demonstrate their acceptance of the new structure of the game and their adaptation to the new habitus, thus enabling them to accumulate greater stocks of capital in terms of reputation and regulatory ratings. The role accounting played in the wider social housing field was also evident in its effects on the sub-fields in terms of driving change to the structure and habitus of these fields. While this was not the focus of our study, it is instructive to note that we do not find any evidence of the use of accounting by the dominated players on the field (tenants) as a tool for resistance. Instead, what seems evident is their fatalistic acceptance, in the face of the state's power, of the neolibralization of their field. Thus, by looking through the lens of Bourdieu's concepts, it becomes apparent the partisan role accounting plays in advancing the neoliberal ideology.

These insights generated by deploying Bourdieu's concepts as the theoretic and analytic lens through which we studied the changes in the English social housing field highlight the value of his concepts in studying sociohistorical change in terms of transformation and reproduction of systems of domination. However, while Bourdieu's concepts of field, capital and habitus provided us with a valuable lens through which to view the neoliberalization process of social housing in England and how accounting was implicated in them, we are keenly aware of the challenges these theoretical concepts also posed to us. Indeed, in studies like this which rely on historical data, a more detailed analysis of how habitus changed, how capital was accumulated and converted and the struggles and resistance within the field is impossible. For this type of more detailed study, an ethnography or indeed oral historical accounts from participants might be more useful. We are also conscious of the theoretic limitations of Bourdieu's concepts as being materialist (Yank, 2014) and preoccupied with symbolic violence (Colaguori, 2010), as such this paper does not address more discursive aspects and wider disciplinary modalities (Foucault, 1979) of neoliberalization. Nevertheless, we hope that with our study, we have illuminated a path for future researchers to tread.

\section{Conclusions}

This study situates itself within the ongoing project amongst critical accounting scholars which seeks to account for the role of accounting in organisation and society. We do this through an exploration of how accounting is implicated in the neoliberal reform of the social housing sector in England. We depart from the traditional view of neoliberalism which views it as a static 'end-state' and instead take a processual view of it as neoliberalization which imbues it with dynamism and social character. This creates the scope to deploy Bourdieu's $(1977,1990$, 2005) triad of field, capital and habitus as the theoretical lens through which to explore the process of the neoliberal reform of introducing a new regulatory framework for social housing in England.

We show that the neoliberalization process of the social housing field is instigated by state intervention to change the structure of the field in term of norms, power relations and positions 
of players on the field. These changes are aimed at introducing and naturalising the economic logic as the dominant logic of the field and they simultaneously drive changes in the habitus of the field as players adapt to embrace economic logic over social logic.

We also highlight how these changes instigated by the state were deliberately targeted at strengthening the power and position of the HCA and HAs while at the same time weakening the power and position of tenants in the field. Thus, creating and reproducing a new system of domination. We also demonstrate how accounting is implicated in the creation and reproduction of this new system of domination in the social housing field. While our study goes some way to illuminate the role of accounting in society generally and more specifically, the social construction of neoliberal regulation and regulatory reform, there is still a lot that we do not know in these areas. We have focused on the regulatory reform of social housing, a focus on other social contexts might produce more insight. We find four ways in which accounting is implicated in the process of the neoliberalization processes of regulatory reform but are hopeful that further studies adopting other theoretical lenses like Foucault's (1979) 'governmentality' or Schatzki's $(1996,2005,2012)$ 'theory of practice' illuminate more brightly the role accounting plays in neoliberalization processes and in society more generally. Furthermore, future research may explore how accounting is implicated in crisis resulting from neoliberal reforms of social housing in England such as the recent Grenfell Towers fire disaster in London (McKee, 2017). We hope that our study will serve as a reference point for further studies in this area. 


\section{Appendix 1 - List of Acronyms}

xxxx Insert Table 4 here $x x x x$

\section{Appendix 2 - Data Sources Referred to Specifically}

xxxx Insert Table 5 here $\mathrm{xxxx}$

\section{Appendix 3 - Data Sources}

xxxx Insert Table 6 here xxxx

\section{References}

Anderson, A. R. (2000b). The Protean Entrepreneur: The Entrepreneurial Process As Fitting Self And Circumstance. Journal of Enterprising Culture, 08(03), 201-234.

Anderson, A. R., Dodd, S. D., \& Jack, S. (2010). Network practices and entrepreneurial growth. Scandinavian Journal of Management, 26(2), 121-133.

Anderson, A. R., \& Jack, S. L. (2002). The articulation of social capital in entrepreneurial networks: a glue or a lubricant? Entrepreneurship \& Regional Development, 14(3), 193-210.

Anderson, P. (2000a). Renewals. New Left Review, 1, 5.

Andrew, J. (2007). Prisons, the profit motive and other challenges to accountability. Critical Perspectives on Accounting, 18(8), 877-904.

Andrew, J., \& Cahill, D. (2016). Rationalising and resisting neoliberalism: The uneven geography of costs. Critical Perspectives on Accounting. https://doi.org/10.1016/j.cpa.2016.09.001

Andrew, J., Kaidonis, M. A., \& Andrew, B. (2010). Carbon tax: Challenging neoliberal solutions to climate change. Critical Perspectives on Taxation, 21(7), 611-618.

Arnold, P. J. (2009). Global financial crisis: The challenge to accounting research. Accounting, Organizations and Society, 34(6), 803-809. 
Arnold, P. J., \& Cooper, C. (1999). A Tale of Two Classes: The Privatisation of Medway Ports. Critical Perspectives on Accounting, 10(2), 127-152.

Artiach, T. C., Irvine, H., Mack, J., Ryan, C., \& Parker, L. (2016). the legitimising processes of a new regulator: the case of the australian charities and not-for-profits commission. Accounting, Auditing \& Accountability Journal, 29(5), 802 - 827.

Boeije, H. (2002). A purposeful approach to the constant comparative method in the analysis of qualitative interviews. Quality \& Quantity, 36(4), 391-409.

Bourdieu, P. (1962). The Algerians. Boston: Beacon Press.

Bourdieu, P. (1977). Outline of a Theory of Practice. New York: Cambridge University Press. Bourdieu, P. (1984a). Distinction: A Social Critique of the Judgement of Taste. Cambridge: Harvard University Press.

Bourdieu, P. (1984b). Homo Academicus. Standord: Stanford University Press.

Bourdieu, P. (1986). The forms of capital. In Cultural theory: An anthology (pp. 81-93).

Bourdieu, P. (1990). The Logic of Practice. California: Stanford University Press.

Bourdieu, P. (1991). The political ontology of Martin Heidegger. Standord: Stanford University Press.

Bourdieu, P. (1993). Sociology in Question. London: Sage Publications (CA).

Bourdieu, P. (1996a). The rules of art: Genesis and structure of the literary field. Standord: Stanford University Press.

Bourdieu, P. (1996b). The State Nobility: Elite Schools in the Field of Power. Standord: Stanford University Press.

Bourdieu, P. (1998a). Practical Reason: On the Theory of Action. California: Stanford University Press. 
Bourdieu, P. (1998b). The Essence of Neoliberalism: What is Neoliberalism?: A Programme for Destroying Collective Structures which May Impede the Pure Market Logic: Utopia of Endless Exploitation. Le Monde Diplomatique.

Bourdieu, P. (2005). The Social Structures of the Economy. Cambridge: Wiley.

Bourdieu, P. (2008). The bachelors' ball: The crisis of peasant society in Bearn. Cambridge: Polity Press.

Bourdieu, P., \& Passeron, J. C. (1977). Reproduction in education, culture and society. London: Sage.

Bourdieu, P., \& Wacquant, L. J. D. (1992). An Invitation to Reflexive Sociology. Cambridge: Polity Press.

Brenner, N., Peck, J., \& Theodore, N. (2010a). After Neoliberalization? Globalizations, 7(3), $327-345$.

Brenner, N., Peck, J., \& Theodore, N. (2010b). Variegated neoliberalization: geographies, modalities, pathways. Global Networks, 10(2), 182-222.

Brenner, N., \& Theodore, N. (2002). Cities and the Geographies of "Actually Existing Neoliberalism." Antipode, 34(3), 349-379.

Burchell, S., Clubb, C., \& Hopwood, A. G. (1985). Accounting in its social context: Towards a history of value added in the United Kingdom. Accounting, Organizations and Society, 10(4), $381-413$.

Burchell, S., Clubb, C., Hopwood, A., Hughes, J., \& Nahapiet, J. (1980). The roles of accounting in organizations and society. Accounting, Organizations and Society, 5(1), 5-27.

Canning, M., \& O’Dwyer, B. (2013). The dynamics of a regulatory space realignment: Strategic responses in a local context. Accounting, Organizations and Society, 38(3), 169-194.

Castree, N. (2010). Neoliberalism and the Biophysical Environment 1: What "Neoliberalism" is, and What Difference Nature Makes to it. Geography Compass, 4(12), 1725-1733.

Cave, M. (2007). Every Tenant Matters: A Review of Social Housing Regulation. Communities and Local Government Publication. 
Chiapello, E. (2016). Critical accounting research and neoliberalism. Critical Perspectives on Accounting. https://doi.org/10.1016/j.cpa.2016.09.002

Chomsky, N. (1999). Profit Over People: Neoliberalism and Global Order. London: Seven Stories Press.

Colaguori, C. (2010). Symbolic violence and the violation of human rights: Continuing the sociological critique of domination. International Journal of Criminology and Sociological Theory, 3(2).

Cole, B., \& Cooper, C. (2006). Deskilling in the 21 st century: The case of rail privatisation. Labour Process, 17(5), 601-625.

Collier, P. M. (2005). Governance and the quasi-public organization: a case study of social housing. Critical Perspectives on Accounting, 16(7), 929-949.

Cooper, C. (1995). Ideology, hegemony and accounting discourse: a case study of the National Union of Journalists. Critical Perspectives on Accounting, 6(3), 175-209.

Cooper, C., \& Coulson, A. B. (2014). Accounting activism and Bourdieu's 'collective intellectual' - Reflections on the ICL Case. Critical Perspectives on Accounting, 25(3), 237254.

Cooper, C., Coulson, A., \& Taylor, P. (2011). Accounting for human rights: Doxic health and safety practices - The accounting lesson from ICL. Accounting For Human Rights Accounting For Human Rights, 22(8), 738-758.

Cooper, D. J., \& Sherer, M. J. (1984). The value of corporate accounting reports: Arguments for a political economy of accounting. Accounting, Organizations and Society, 9(3-4), 207232.

Cressey, D. R. (1953). Other people's money; a study of the social psychology of embezzlement. New York: Free Press.

Crotty, J. (2000). Structural Contradictions of the Global Neoliberal Regime. Review of Radical Political Economics, 32(3), 361-368. 
Daly, G., Mooney, G., Poole, L., \& Davis, H. (2005). Housing stock transfer in Birmingham and Glasgow: the contrasting experiences of two UK cities. European Journal of Housing Policy, 5(3), 327-341.

Dardot, P., \& Laval, C. (2010). Nouvelle raison du monde. Paris: La Découverte.

Davies, W. (2017). The Limits of Neoliberalism: Authority, Sovereignty and the Logic of Competition (Revised Edition). London: SAGE Publications, Limited.

Department for Communities and Local Government. (2017). Dwelling Stock Estimates: 2016, England. Department for Communities and Local Government. Retrieved from https://www.gov.uk/government/uploads/system/uploads/attachment_data/file/609282/Dwelli ng_Stock_Estimates_2016_England.pdf

Department for Communities and Local Government. (2010). Review of social housing regulation. Department for Communities and Local Government.

Dillard, J. F. (1991). Accounting as a critical social science. Accounting, Auditing \& Accountability Journal, 4(1).

Dobbin, F. (2008). The poverty of organizational theory: Comment on: "Bourdieu and organizational analysis." Theory and Society, 37(1), 53-63.

Ellwood, S., \& Newberry, S. (2007). Public sector accrual accounting: institutionalising neoliberal principles? Accounting, Auditing \& Accountability Journal, 20(4), 549-573.

Emirbayer, M., \& Johnson, V. (2008). Bourdieu and organizational analysis. Theory and Society, 37(1), 1-44.

England, K. \& Ward, K., (2007). Introduction: Reading Neoliberalization. In Ward, K., \& England, K. (Eds), Neoliberalization (pp. 1-22). Oxford: Blackwell Publishing Ltd.

Everett, J. (2002). Organizational Research and the Praxeology of Pierre Bourdieu. Organizational Research Methods, 5(1), 56-80.

Foucault, M. (1979). On governmentality. Ideology \& Consciousness, (6), 5-21.

Foucault, M. (2008). The Birth of Biopolitics: Lectures at the Collège de France, 1978-1979. New York: Palgrave Macmillan. 
Fourcade, M., \& Healy, K. (2013). Classification situations: Life-chances in the neoliberal era. Accounting, Organizations and Society, 38(8), 559-572.

Gallhofer, S., Haslam, J., \& Yonekura, A. (2015). Accounting as differentiated universal for emancipatory praxis: Accounting delineation and mobilisation for emancipation(s) recognising democracy and difference. Accounting, Auditing \& Accountability Journal, 28(5), 846-874.

Golsorkhi, D., Leca, B., Lounsbury, M., \& Ramirez, C. (2009). Analysing, Accounting for and Unmasking Domination: On Our Role as Scholars of Practice, Practitioners of Social Science and Public Intellectuals. Organization, 16(6), 779-797.

Gorski, P. S. (2013). Introduction: Bourdieu as a theorist of change. In P. S. Gorski (Ed.), Bourdieu and historical analysis (pp. 1-15). Durham and London: Duke University Press.

Gracia, L., \& Oats, L. (2012). Boundary work and tax regulation: A Bourdieusian view. Accounting, Organizations and Society, 37(5), 304-321.

Grenfell, M. J. (2014). Pierre Bourdieu: Key Concepts. New York, NY.: Routledge.

Grenfell, M., \& James, D. (2004). Change in the field — changing the field: Bourdieu and the methodological practice of educational research. British Journal of Sociology of Education, 25(4), 507-523.

Harvey, D. (2007). A brief history of neoliberalism. Oxford University Press, USA.

Heynen, N., \& Robbins, P. (2005). The neoliberalization of nature: Governance, privatization, enclosure and valuation. Capitalism Nature Socialism, 16(1), 5-8.

Hodkinson, S., \& Robbins, G. (2013). The return of class war conservatism? Housing under the UK Coalition Government. Critical Social Policy, 33(1), 57-77.

Homes and Communities Agency. (2012). The Regulatory Framework For Social Housing In England From April 2012. Homes and Communities Agency.

Hopwood, A. G., (1976).(Editorial). The path ahead. Accounting, Organizations and Society, $1(1), 1-4$.

Hopwood, A. G. (1983). On trying to study accounting in the contexts in which it operates. Accounting, Organizations and Society, 8(2), 287-305. 
Hopwood, A. G. (1985). The tale of a committee that never reported: Disagreements on intertwining accounting with the social. Accounting, Organizations and Society, 10(3), 361377.

Hopwood, A. (1994), “Accounting and the pursuit of efficiency”, in McKevitt, D and Lawton, A (Eds.), Public Sector Management: Theory, Critique and Practice, London: Sage.

Jack, S. L., \& Anderson, A. R. (2002). The effects of embeddedness on the entrepreneurial process. Qualitative Methods in Entrepreneurial Research, 17(5), 467-487.

Jack, S., Moult, S., Anderson, A. R., \& Dodd, S. (2010). An entrepreneurial network evolving: Patterns of change. International Small Business Journal, 28(4), 315-337.

Jackson, A., \& Lapsley, I. (2003). The diffusion of accounting practices in the new "managerial" public sector. International Journal of Public Sector Management, 16(5), 359372.

Jackson, W. J., Paterson, A. S., Pong, C. K. M., \& Scarparo, S. (2013). Doctors under the microscope: the birth of medical audit. Accounting History Review, 23(1), 23-47.

Jenkins, R. (2002). Pierre Bourdieu. New York: Routledge.

Jupe, R. (2009). New Labour, Network Rail and the third way. Accounting, Auditing \& Accountability Journal, 22(5), 709-735.

Jupe, R., \& Funnell, W. (2015). Neoliberalism, consultants and the privatisation of public policy formulation: The case of Britain's rail industry. Critical Perspectives on Accounting, $29,65-85$.

Katz, J. (2001). Analytic induction. In N. J. Smelser \& B. Baltes (Eds.), International Encyclopaedia of the Social and Behavioral Sciences (pp. 1--480). Oxford: Elsevier.

Kitchin, P. J., \& Howe, P. D. (2014). The mainstreaming of disability cricket in England and Wales: Integration 'One Game' at a time. Managing Disability Sport, 17(1), 65-77.

Kuruppu, C., Adhikari, P., Gunarathna, V., Ambalangodage, D., Perera, P., \& Karunarathna, C. (2016). Participatory budgeting in a Sri Lankan urban council: A practice of power and domination. Critical Perspectives on Accounting, 41, 1-17. 
Levi-Faur, D. (2009). Regulatory capitalism and the reassertion of the public interest. Policy and Society, 27(3), 181-191.

MacDonald, L. D., \& Richardson, A. J. (2004). Identity, appropriateness and the construction of regulatory space: the formation of the Public Accountant's Council of Ontario. Accounting, Organizations and Society, 29(5), 489-524.

Maclean, M., Harvey, C., \& Chia, R. (2012). Sensemaking, storytelling and the legitimization of elite business careers. Human Relations, 65(1), 17-40.

Madsen, M. R., \& Dezalay, Y. (2002). The Power of the Legal Field: Pierre Bourdieu and the Law. In M. T. Reza Banakar (Ed.), An Introduction To Law and Social Theory (pp. 189-207). Oxford: Hart Publishing.

Malpass, P. (1999). Housing Associations and Housing Policy in Britain Since 1989. Housing Studies, 14(6), 881-893.

Malpass, P. (2000). The Discontinuous History of Housing Associations in England. Housing Studies, 15(2), 195-212.

Malpass, P. (2001). The Uneven Development of "Social Rented Housing": Explaining the Historically Marginal Position of Housing Associations in Britain. Housing Studies, 16(2), $225-242$.

Malsch, B., \& Gendron, Y. (2011). Reining in auditors: On the dynamics of power surrounding an "innovation" in the regulatory space. Accounting, Organizations and Society, 36(7), 456476.

Malsch, B., Gendron, Y., \& Grazzini, F. (2011). Investigating interdisciplinary translations: The influence of Pierre Bourdieu on accounting literature. Accounting, Auditing \& Accountability Journal, 24(2), 194-228.

Mansfield, B. (2004). Rules of Privatization: Contradictions in Neoliberal Regulation of North Pacific Fisheries. Annals of the Association of American Geographers, 94(3), 565-584.

Manville, G., Greatbanks, R., Wainwright, T., \& Broad, M. (2016). Visual performance management in housing associations: a crisis of legitimation or the shape of things to come? Public Money \& Management, 36(2), 105-112. 
Marx, K., \& Engels, F. (2002). The communist manifesto. London: Penguin.

McKee, M. (2017). Grenfell Tower fire: why we cannot ignore the political determinants of health. BMJ, 357.

Morales, J., Gendron, Y., \& Guénin-Paracini, H. (2014). State privatization and the unrelenting expansion of neoliberalism: The case of the Greek financial crisis. Critical Perspectives on Accounting, 25(6), 423-445.

Mullins, D. (2000). Social Origins and Transformations: The Changing Role of English Housing Associations. Voluntas: International Journal of Voluntary \& Nonprofit Organizations, 11(3), 255-275.

Mullins, D. (2010). Housing associations. Third Sector Research Centre. Working Paper 16

Parker, L. (2011). University corporatisation: driving redefinition. Critical Perspectives on Accounting, 22(4), 434-450.

Peck, J., \& Theodore, N. (2012). Reanimating neoliberalism: process geographies of neoliberalisation. Social Anthropology, 20(2), 177-185.

Peck, J., Theodore, N., \& Brenner, N. (2010). Postneoliberalism and its Malcontents. Antipode, $41,94-116$.

Peck, J., Theodore, N., \& Brenner, N. (2012). Neoliberalism Resurgent? Market Rule after the Great Recession. South Atlantic Quarterly, 111(2), 265-288.

Peck, J., \& Tickell, A. (2002). Neoliberalizing Space. Antipode, 34(3), 380-404.

Plehwe, D., Walpen, B. J. A., \& Neunhöffer, G. (2007). Neoliberal Hegemony: A Global Critique. Oxon: Routledge.

Polanyi, K. (1944). The Great Transformation. Boston: Beacon Press.

Robinson, W. S. (1951). The Logical Structure of Analytic Induction. American Sociological Review, 16(6), 812-818.

Rose, N. (1991). Governing by numbers: Figuring out democracy. Accounting, Organizations and Society, 16(7), 673-692. 
Schatzki, T. R. (1996). Social practices: A Wittgensteinian approach to human activity and the social. Cambridge: Cambridge Univ Press.

Schatzki, T. R. (2005). Peripheral Vision. Organization Studies, 26(3), 465-484.

Schatzki, T. R. (2012). A Primer on Practices. In J. Higgs, R. Barnett, S. Billett, M. Hutchings, \& F. Trede (Eds.), Practice-Based Education: Perspectives and Strategies (pp. 13-26). Rotterdam: Sense Publishers.

Smyth, S. (2012). Contesting public accountability: A dialogical exploration of accountability and social housing. Accountability Special Issue for CPA, 23(3), 230-243.

Spence, C., \& Carter, C. (2014). An exploration of the professional habitus in the Big 4 accounting firms. Work, Employment and Society, 28(6), 946-962.

Stephens, M., \& Stephenson, A. (2016). Housing policy in the austerity age and beyond. Social Policy Review 28: Analysis and Debate in Social Policy, 2016, 28, 63.

Stringfellow, L., McMeeking, K., \& Maclean, M. (2015). From four to zero? The social mechanisms of symbolic domination in the UK accounting field. Critical Perspectives on Accounting, 27, 86-100.

Tenant Services Authority. (2010). The regulatory framework for social housing in England from April 2010. Tenant Services Authority.

Tickell, A., \& Peck, J. (2003). Making global rules: Globalisation or neoliberalisation. In Remaking the global economy: Economic-geographical perspectives (pp. 163-182). London: Sage.

Tinker, A. M. (1980). Towards a political economy of accounting: An empirical illustration of the Cambridge controversies. Accounting, Organizations and Society, 5(1), 147-160.

Tinker, A. M., Merino, B. D., \& Neimark, M. D. (1982). The normative origins of positive theories: Ideology and accounting thought. Accounting, Organizations and Society, 7(2), 167200. 
Together Housing Group. (2017). Annual Report 2016/17. Together Housing Group. Retrieved from https://www.togetherhousing.co.uk/media/2415942/th-annual-report-2017-fvspreads.pdf

Walker, S. P. (2016). Revisiting the roles of accounting in society. Reflecting on 40 Years of Accounting, Organizations and Society - Part II, 49, 41-50.

Whitfield, D. (2006). New Labour's attack on public services. Nottingham: Spokesman.

Wright, A. L. (2009). Domination in Organizational Fields: It's Just Not Cricket. Organization, $16(6), 855-885$.

Xu, Y., \& Xu, X. (2008). Social actors, cultural capital, and the state: The standardization of bank accounting classification and terminology in early twentieth-century China. Accounting, Organizations and Society, 33(1), 73-102.

Yang, Y. (2014). Bourdieu, Practice and Change: Beyond the criticism of determinism. Educational Philosophy and Theory, 46(14), 1522-1540.

Young, J. J. (1994). Outlining regulatory space: Agenda issues and the FASB. Accounting, Organizations and Society, 19(1), 83-109.

Young, J. J. (1995). Getting the accounting "right": Accounting and the savings and loan crisis. Accounting, Organizations and Society, 20(1), 55-80.

Zhang, Y., \& Andrew, J. (2014). Financialisation and the Conceptual Framework. Special Issue on Critical Perspectives on Financialization, 25(1), 17-26.

Zhang, Y., Andrew, J., \& Rudkin, K. (2012). Accounting as an instrument of neoliberalisation? Exploring the adoption of fair value accounting in China. Accounting, Auditing \& Accountability Journal, 25(8), 1266-1289. 


\section{Figure 1}

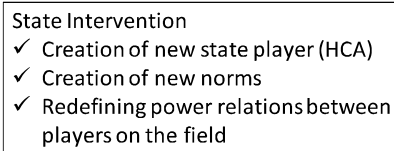

Players respond to the new structure of the

game by adapting

their 'game' to

privilege economic logic and casting off

the 'burden' of social

logic. 
Table 1

\begin{tabular}{|l|l|}
\hline $\begin{array}{c}\text { Accounting } \\
\text { Concept and } \\
\text { Practices }\end{array}$ & \multicolumn{1}{c|}{ Detail of Deployment } \\
\hline Transparency & $\begin{array}{l}\text { HAs and their governing bodies should be transparent with their tenants, } \\
\text { service users and other stakeholders. }\end{array}$ \\
\hline Accountability & $\begin{array}{l}\text { The governing body of HAs are responsible and accountable for } \\
\text { delivering the organisations objectives and compliance with the } \\
\text { regulatory standards. They are also accountable to stakeholders and } \\
\text { tenants for service delivery, and dealing with actual and potential } \\
\text { problems. }\end{array}$ \\
\hline Governance & $\begin{array}{l}\text { HAs are to adopt and comply with an appropriate code } \\
\text { of corporate governance, which should be followed using the comply or } \\
\text { explain principle. }\end{array}$ \\
\hline $\begin{array}{l}\text { Financial } \\
\text { Viability }\end{array}$ & $\begin{array}{l}\text { HAs are to have robust business planning and control mechanisms which } \\
\text { ensure sufficient liquidity, risk management and compliance with funders } \\
\text { financial covenants. }\end{array}$ \\
\hline $\begin{array}{l}\text { Value for } \\
\text { Money }\end{array}$ & $\begin{array}{l}\text { HAs are required to articulate and deliver a comprehensive and strategic } \\
\text { approach to achieving value for money in meeting their organisation's } \\
\text { objectives. }\end{array}$ \\
\cline { 2 - 3 } & $\begin{array}{l}\text { HAs are to ensure a prudent and planned approach to repairs and } \\
\text { maintenance of homes which demonstrates value for money. }\end{array}$ \\
\hline $\begin{array}{l}\text { Calculative } \\
\text { practices }\end{array}$ & $\begin{array}{l}\text { Rents are to be calculated by a formula which is based on relative } \\
\text { property values, relative local earnings and size of the house. Rent } \\
\text { increases are calculated by a formula benchmarked against the retail price } \\
\text { index. }\end{array}$ \\
\hline
\end{tabular}


Table 2

\begin{tabular}{|c|c|c|}
\hline & Labour & Lib Dem/Conservative Coalition \\
\hline $\begin{array}{l}\text { Consultation } \\
\text { questions }\end{array}$ & $\begin{array}{l}\text { Does the proposed text for the } \\
\text { Value for Money standard: } \\
\text { - address priorities for tenants } \\
\text { whilst taking into account our } \\
\text { duty to have regard to the } \\
\text { desirability of registered } \\
\text { providers being free to choose } \\
\text { how to provide services and } \\
\text { conduct their business? }\end{array}$ & $\begin{array}{l}\text { Does the revised Value for Money } \\
\text { standard: } \\
\text { - Give providers sufficient flexibility to } \\
\text { run their businesses? } \\
\text { - Enable the regulator to provide } \\
\text { adequate protection to taxpayers' } \\
\text { interests, and to maintain the } \\
\text { confidence of lenders and } \\
\text { stakeholders in the regulator's } \\
\text { economic role? }\end{array}$ \\
\hline $\begin{array}{l}\text { Requirement } \\
\text { of the Value } \\
\text { for Money } \\
\text { standard }\end{array}$ & $\begin{array}{l}\text { In meeting all national standards } \\
\text { and their local standards, } \\
\text { registered providers have a } \\
\text { comprehensive approach to } \\
\text { managing their resources to } \\
\text { provide cost-effective, efficient, } \\
\text { quality services and homes to } \\
\text { meet tenants' and potential } \\
\text { tenants' needs. }\end{array}$ & $\begin{array}{l}\text { Registered providers shall articulate and } \\
\text { deliver a comprehensive and strategic } \\
\text { approach to achieving value for money } \\
\text { in meeting their organisation's } \\
\text { objectives..... This means managing } \\
\text { their resources economically, efficiently } \\
\text { and effectively to provide quality } \\
\text { services and homes, and planning for } \\
\text { and delivering on-going improvements } \\
\text { in value for money. }\end{array}$ \\
\hline
\end{tabular}


Table 3

\begin{tabular}{|c|c|}
\hline Quote & Impact on the organisation \\
\hline $\begin{array}{l}\text { "We aim to have a culture which is tighter and } \\
\text { more focused around value for money, sustained } \\
\text { by looking outwards to what others are doing and } \\
\text { to bring us in line with the best and with a positive } \\
\text { customer centred ethos." (Clone Housing, 2016) }\end{array}$ & $\begin{array}{l}\text { Organisational culture is } \\
\text { intentionally being focused around } \\
\text { value for money. The organisation } \\
\text { beginning to benchmark its activities } \\
\text { against other players in the field. }\end{array}$ \\
\hline $\begin{array}{l}\text { "Driving up the performance of our staff: } \\
\text { Overseen by our Human Resources \& } \\
\text { Remuneration Committee consisting of a panel of } \\
\text { Board members, our Performance Management } \\
\text { Framework ensures that staff performance is } \\
\text { robustly managed and good performance } \\
\text { rewarded. Our aim is to maximise the VFM we } \\
\text { get from our staff, especially important as } \\
\text { staffing costs are c40\% of our total operational } \\
\text { expenditure." (One Housing, 2016) }\end{array}$ & $\begin{array}{l}\text { Value for money is leading to a focus } \\
\text { on staff performance and efficiency. } \\
\text { A possible impact of this is work } \\
\text { intensification for the staff resulting } \\
\text { from HAs seeking to achieve value } \\
\text { for money from staff. }\end{array}$ \\
\hline $\begin{array}{l}\text { "Specific VfM objectives aligned to the business } \\
\text { plan which are developed and cascaded through } \\
\text { member organisations, Directorates, teams and } \\
\text { employees. Performance against these objectives } \\
\text { is monitored on a regular basis ensuring that VfM } \\
\text { remains central to the Group's activities. VfM } \\
\text { implications are also highlighted for key Board } \\
\text { decisions to ensure that there has been full } \\
\text { consideration of the relevant issues." (Symphony } \\
\text { Housing Group, 2016) }\end{array}$ & $\begin{array}{l}\text { Value for money is embedded in the } \\
\text { organisations strategic planning and } \\
\text { affects all aspects of the business. } \\
\text { Value for money is also becoming } \\
\text { central to decision making at the top } \\
\text { and other levels of the organisation }\end{array}$ \\
\hline
\end{tabular}


Table 4

\begin{tabular}{|l|l|}
\hline Full Name & Acronym \\
\hline Large scale voluntary transfers & LSVTs \\
\hline Housing Associations & HAs \\
\hline Tenants Services Authority & TSA \\
\hline Homes and Communities Agency & HCA \\
\hline Department for Communities and Local Government & DCLG \\
\hline Together Housing Group & THG \\
\hline Tenants and Resident Organisations of England & TAROE \\
\hline Tenant Participation Advisory Service & TPAS \\
\hline Acclaim Housing Group & AHG \\
\hline Gloucester City Homes & GCH \\
\hline National Housing Federation & NHF \\
\hline
\end{tabular}


Table 5

\begin{tabular}{|c|c|}
\hline In Text Reference & Data Source \\
\hline Acclaim Housing Group (2014) & $\begin{array}{l}\text { Acclaim Housing Group Value for Money Self-Assessment, } \\
2014\end{array}$ \\
\hline Brown (2014) & $\begin{array}{l}\text { Number of paid board Members surges | News | Inside } \\
\text { Housing. (2014, March 21) }\end{array}$ \\
\hline Clone Housing (2016) & Clone Housing Value for Money Self-Assessment, 2016 \\
\hline Cowley (2014) & $\begin{array}{l}\text { Sector conflicted on board pay as top earning HA chair receives } \\
£ 65,000 \mid \text { Special Reports | Social Housing. (2014, May 2) }\end{array}$ \\
\hline DCLG (2010) & Review of social housing regulation \\
\hline Gloucester City Homes (2016) & $\begin{array}{l}\text { Gloucester City Homes Value for Money Self-Assessment, } \\
2016\end{array}$ \\
\hline Grant Thornton (2016) & Housing Governance Review, 2016 \\
\hline HCA (2012) & $\begin{array}{l}\text { The Regulatory Framework for Social Housing in England } \\
\text { From April } 2012\end{array}$ \\
\hline Inside Housing (2016) & Meet the board | Analysis | Inside Housing. (2016, June 22) \\
\hline Inside Housing (2017) & $\begin{array}{l}\text { Inaccurate financial reporting sees landlord downgraded by } \\
\text { HCA | News | Inside Housing. (2017, January 6) }\end{array}$ \\
\hline One Housing (2016) & One Housing Value for Money Self-Assessment, 2016 \\
\hline Regulatory Judgement H1046 & HCA Regulatory Judgement on The Abbeyfield Society \\
\hline $\begin{array}{l}\text { Regulatory Judgement, } \\
\text { LH0269 }\end{array}$ & HCA Regulatory Judgement on Brunelcare \\
\hline $\begin{array}{l}\text { Symphony Housing Group } \\
(2016)\end{array}$ & $\begin{array}{l}\text { Symphony Housing Group Value for Money Self-Assessment, } \\
2016\end{array}$ \\
\hline TAROE (2012) & $\begin{array}{l}\text { TAROE Response to Consultation: A Revised Regulatory } \\
\text { Framework for Social Housing in England From April 2012: A } \\
\text { Statutory Consultation }\end{array}$ \\
\hline TPAS (2012) & $\begin{array}{l}\text { TPAS Response to Consultation: A Revised Regulatory } \\
\text { Framework for Social Housing in England From April 2012: A } \\
\text { Statutory Consultation }\end{array}$ \\
\hline TSA (2009) & $\begin{array}{l}\text { A New Regulatory Framework for Social Housing in England: } \\
\text { A Statutory Consultation }\end{array}$ \\
\hline TSA (2012) & $\begin{array}{l}\text { A Revised Regulatory Framework for Social Housing in } \\
\text { England From April 2012: A Statutory Consultation }\end{array}$ \\
\hline
\end{tabular}


Table 6

\begin{tabular}{|c|c|c|}
\hline Document & Number & Source \\
\hline $\begin{array}{l}\text { Cave Review of Social Housing Responses to } \\
\text { Call for Evidence }\end{array}$ & 112 & National Archive \\
\hline $\begin{array}{l}\text { The Cave Review of Social Housing Final } \\
\text { Report }\end{array}$ & 1 & National Archive \\
\hline $\begin{array}{l}\text { TSA Consultation 2009: A New Regulatory } \\
\text { Framework for Social Housing in England: A } \\
\text { Statutory Consultation }\end{array}$ & 1 & National Archive \\
\hline $\begin{array}{l}\text { TSA Publication: The regulatory framework for } \\
\text { social housing in England from April } 2010 \\
\text { Analysis of respondents' views }\end{array}$ & 1 & National Archive \\
\hline $\begin{array}{l}\text { TSA Consultation 2012: A Revised Regulatory } \\
\text { Framework for Social Housing in England } \\
\text { From April 2012: A Statutory Consultation }\end{array}$ & 1 & National Archive \\
\hline $\begin{array}{l}\text { Responses to TSA Consultation 2012: A } \\
\text { Revised Regulatory Framework for Social } \\
\text { Housing in England From April 2012: A } \\
\text { Statutory Consultation }\end{array}$ & 250 & National Archive \\
\hline $\begin{array}{l}\text { TSA Publication: A Revised Regulatory } \\
\text { Framework for Social Housing in England } \\
\text { From April 2012: Analysis of respondents' } \\
\text { views }\end{array}$ & 1 & National Archive \\
\hline $\begin{array}{l}\text { The Regulatory Framework for Social Housing } \\
\text { in England From April } 2012\end{array}$ & 1 & HCA Website \\
\hline $\begin{array}{l}\text { The Regulatory Framework for Social Housing } \\
\text { in England From April } 2010\end{array}$ & 1 & National Archive \\
\hline HCA Publication: Regulating the Standards & 1 & HCA Website \\
\hline $\begin{array}{l}\text { Grant Thornton Publication: Housing } \\
\text { Governance Review (2014 - 2016) }\end{array}$ & 3 & Grant Thornton Website \\
\hline $\begin{array}{l}\text { Inside Housing Articles (News, Analysis and } \\
\text { Data) }\end{array}$ & 40 & $\begin{array}{l}\text { Inside Housing Web } \\
\text { Archive }\end{array}$ \\
\hline $\begin{array}{l}\text { Social Housing Articles (News, Analysis and } \\
\text { Data) }\end{array}$ & 28 & $\begin{array}{l}\text { Social Housing Web } \\
\text { Archive }\end{array}$ \\
\hline HCA Regulatory Judgements & 235 & HCA Website \\
\hline TSA Regulatory Judgements & 70 & National Archive \\
\hline $\begin{array}{l}\text { Value for Money Self-Assessments for } 81 \mathrm{HAs} \\
(2014 / 15-2015 / 16)\end{array}$ & 162 & HA Websites \\
\hline
\end{tabular}

